\title{
City-City Tourism Collaboration in the Straits of Malacca Development Region: Key Success Factors
}

\author{
A. Habibah ${ }^{1,2}$, J. Hamzah ${ }^{1}$, A. C. Er ${ }^{1}$, A. Buang ${ }^{1}$, S. Selvadurai ${ }^{1} \&$ I. Mushrifah ${ }^{2}$ \\ ${ }^{1}$ School of Social, Development and Environmental Studies, Faculty of Social Sciences and Humanities, \\ Universiti Kebangsaan Malaysia, Bangi, Malaysia \\ ${ }^{2}$ Tasik Chini Research Centre, Faculty of Science and Technology, Universiti Kebangsaan Malaysia, Malaysia \\ Correspondence: A. Habibah, School of Social, Development and Environmental Studies, Faculty of Social \\ Sciences and Humanities, Universiti Kebangsaan Malaysia, Bangi 43600, Malaysia. E-mail: ha@ukm.my
}

Received: September 17, 2012 Accepted: June 17, $2013 \quad$ Online Published: September 29, 2013

doi:10.5539/ass.v9n13p40

URL: http://dx.doi.org/10.5539/ass.v9n13p40

\begin{abstract}
City to city collaboration has emerged as one of the regional initiatives to promote and sustained economic growth in many parts around the world. Within the Asean cooperation, city to city tourism collaboration is also an emerging sector. Although existing literatures assert on key success factors that lead to economic and cultural collaboration, little has been done to explore and elaborate deeply the key success factors in the city to city (C2C) tourism collaboration the Straits of Malacca Development Region. This article aims to identify key success factors of the city to city tourism collaboration in the Straits of Malacca Development Region, particularly deriving from the Malacca-Riau Provincial's initiatives. This article is based on both qualitative and quantitative data collection undertaken in 2010 in Malacca and Riau-Pekan Baru. The study found that key success factors of $\mathrm{C} 2 \mathrm{C}$ tourism collaboration are the enabling leadership, mutual and shared vision and goals, participating communities and social cultural ties, geographical, interconnectivity and accessibility as well as a growing market demand. The homogeneity in social cultural ties is not a competing factor, instead, is a complementing factor in the $\mathrm{C} 2 \mathrm{C}$ tourism collaboration. It is suggested that all key success factors be considered at different level and scale of collaboration especially at smaller city-city tourism collaboration in the Straits of Malacca Development Region in the near future.
\end{abstract}

Keywords: city-city collaboration, tourism, leadership, participating communities, emerging regional consumer, strait of the Malacca development region

\section{Introduction}

City to city tourism ( $\mathrm{C} 2 \mathrm{C}$ Tourism) is one of the strategic collaborations often been employed and developed in the regional, national, cities, Straits and cross border development (Buis, 2009; Sheffield, 2006; Wong et al., 2011; Kim, 2010; Bramwell \& Sharman, 1999; Ho, 1997; Habitat, 2001). As such, the relevant city stakeholders and practitioners, including city mayors have initiated concerted efforts in materializing these C2Cs in somewhat similar names such as sister cities, twinning city, city cooperation, city collaboration, strategic alliances and city networking (Villier, 2009; Tjandradewi \& Marcutullio, 2009; Jamal \& Getz, 1995; Reid et al., 2008; Mandják et al., 2011). Whatever names that have been suggested and established during the collaborative projects, city to city tourism has created a wide range of opportunities; including economic growth, job creation, heritage enhancement, business and linkages among tourism providers in both cities (Sofield, 2006; Jamal \& Getz, 1995; Aas et al., 2005; Wong et al., 2011; Mandják et al., 2011). Historically, city to city tourism has been practiced by most of the elite classes and colonial kingdom (Evers \& Gerke, 2006; Habibah et al., 2009). Visits from the royal families and elites during the colonial period in Southeast Asia for instant, have provided leisure lifestyles to the masses (Tjandradewi \& Marcotullio, 2009). In contemporary era, C2C tourism collaboration is expected not only to increase intra-flows of tourists between cities, generate value chain between tourism providers but also accelerate the overall economy on both cities and regions of cooperation or collaboration (Shih, 2006; Wong et al., 2011, 2010; Weimer, 2009).

While there are numerous examples from the city to city tourism collaborations in developed countries, the complexity on how the city to city tourism takes place in the Southeast Asian region, growth triangles and in the Straits, development is still understudied. However, it has been a growing body of the Straits collaboration lately 
among ASEAN and the Asia Pacific scholars (Wong et al., 2010, 2011; Kim, 2010; Tjandradewi \& Marcotullio, 2009; Zhi \& Gu, 2009; Shih, 2006). In fact, between the ASEAN countries, tourism collaboration is one of the initiatives often utilized for advancing the ASEAN Economic Community 2015. It is through this initiative that the community will have ample chances to participate more actively not only at the local level but also at the development region. Given the significance of the implementation of the city to city tourism collaboration, the objective of this study is to analyse key success factors in facilitating city to city tourism collaboration in the Straits of Malacca Development region, especially on the Malacca and the Provincials of Riau initiatives.

\section{Materials and Methods}

\subsection{Defining City to City Tourism Collaboration}

To determine what matters in the city-city tourism collaboration, interrelated concepts and approaches including cooperation, collaboration and networking are accessed. The City-city cooperation, a concept coined by Nigel Ringrose (UNDP, 2001) is typically referred as a long-term partnership between communities in different cities or towns based on mutuality and equity. The UN-HABITAT suggested that $\mathrm{C} 2 \mathrm{C}$ cooperation include all possible forms of relationships between local authorities in two or more countries that collaborate together for mutual interest and benefits, with or without external support (Tjandradewia et al., 2006, 2009).

Meanwhile, collaboration is generally defined as a cooperative arrangement in which two or more parties (which may or may not have any previous relationship) work jointly towards a common goal. It includes an effective method of transferring 'know how' among individuals; therefore, critical to creating and sustaining a competitive advantage and negotiations that use both assertiveness and cooperation to seek solutions to all parties. Jamal and Getz (1995) posit collaboration as a process of joint decision making among autonomous, key stakeholders of an inter-organizational, community tourism domain to resolve planning problems of the domain and or to manage issues related to the planning and development within of the domain. Later, d'Angella and Go (2009) define collaboration as a process within joint decision making involving key stakeholders linked in and with the institutions aiming at resolving conflicts and advancing a shared vision and goals.

On the other hand, city networking refers to a development of linkages between actors (organisations \& individuals) where linkages become formalised in a mutual interest (March \& Wilkinson, 2009; Beritelli, 2011). Several authors explored the meanings and applications in the economic undertakings between interested stakeholders, including the financial and investments sector (Hall, 1999; Roper, 2007; Masakatsu, 2004; Shen \& Lin, 2011). Go and Williams (1993) refer network as a type of cooperation that takes the form of neither a merger nor a joint venture. Accordingly, a tourism business network could be viewed as a market in which nodes are connected with service providers who add values by contributing their specific core competencies. To date, Kim (2010) stresses that networking is a form or structure of relation, created by the continuous interaction between various players who play distinctive roles, motivated by interests and aimed to achieve mutual benefits.

Although numerous literatures on the collaboration, borderland integration and networking provide diverse suggestions on key success factors, the geographical importance still helps to facilitate the tourism networking (Ho, 1997; Dredge, 2006). However, Gelbman and Timothy (2011) stress on the varying levels of interaction from little or none in alienating borderlands to a very high integrated borderland. In fact, Go and Van Fenema (2003) stress that collaboration requires both physical and metaphorical inclusion. The physical factor is weighted through equity sharing and participation in decision-making processes while the metaphor is through trust and willingness to share activities, resources and goals. In the business-renewal networks, in particular, Lemmetyinen and Go (2009) emphasise the orchestrating of the network with a shared brand visioning as the critical success factor of a tourism business network to be optimally performed. They also assert on the ability to develop and implement informational, interpersonal and decisional roles from the managerial talents in the coordinating cooperation.

Arnaboldi and Spiller (2011) nevertheless, claim that controversies can still be overcome by deploying three actor-network theory rules: enrolling actors, fact-building and circulating translations. In practice, Ried et al. (2008) agree with the Mistilis and Daniele (2004) and Selin and Chavez's (1995) work on the long term alliances in tourism. It is a dynamic yet a fragile process; as in whatever form of management and governance, responsive administration is needed for each stage of the life cycle of the alliance. Added to this, social learning assisted the river basin management (Mostert et al., 2007), while adaptive collaborative management works best in strong communication, trust, coordination, and legitimate decision making and authority. All these can be built through improved relationships, respecting religion, shared information and culture, socio-political interfacing and institutions (Wollenberg et al., 2007; Masakatsu, 2004; Muñoz-Erickson et al., 2010; Slinger et al., 2010).

All the above concepts propose that key ingredients are interrelated factors encompassing the enabling 
leadership with shared purposes and strategies, realistic relationship and practices, inclusiveness and participating communities and social cultural factors, demand as well as the physical accessibility and spatial interconnectivity (Tjandradewi \& Marcotullio, 2009; Shih, 2006; Beritelli, 2011). In fact there is a growing concern of city collaboration in riverine regions taking the cluster and networking advantages (Kim, 2010). On another note, barriers to city collaboration should not be overlooked, especially factors concerning the sincerity of the collaboration and complimentary functions derived from difference in tourism development stages (Zhu \& $\mathrm{Gu}, 2009$; Brune, 2006).

\subsubsection{C2C in ASEAN Region}

At the ASEAN cooperation level, Wong et al. (2010) emphasise that the formation of collaboration in tourism was driven by necessity mainly supported by the wider political, economic and social agenda. Wong (2011) in his recent study, nevertheless, stressed that the ASEAN collaboration is highly dependent on three major dimensions, stakeholders, resources and process or mechanism that take place within the stakeholder concern. The political will and support, trust among tourism policy providers, cross-border and sub-regional collaboration determined the strength of the stakeholder dimension (Bunnel et al., 2006; Husnaidi, 2006), while resources of financial and human capital determine the latter dimension respectively. However, some authors assert on the effectiveness of the adhoc implementation of tourism programmes and activities such as art and music performances, food fiestas and cultural exchanges in accelerating the tourism growth (Habibah et al., 2009). Taking an example from a successful Singapore as the hub and service centre of tourism, and on the other hand, how challenging than Batam and Bintan have to face in establishing tourism (Effendi, 2009; Bunnell et al., 2006; Litvin \& Ling, 2001), one hardly determine the success factors in tourism collaboration of this region.

Some of the ASEAN tourism scholars were also aware of the limitation progress on the cooperation and partnership (Habibah, 1994; Habibah et al., 2009; Tjandradewi \& Marcotullio, 2009; Wong et al., 2011; Masakatsu, 2004; Gerke \& Evers, 2011). Instead of shared goals and understandings that lead to a more vigorous cooperation, conflicts on the authorship of the products and cultural attributions have weakened the collaboration. The tourism ventures between the states-provincials in growth triangle cooperation, especially the Bintan-Singapore collaboration case provides evidence that not only lopsided advantages exist between business partners. The rising of imbalance of Asiatic core-periphery development further complicated the project initiatives (RSIS, 2007; Ford \& Lyons, 2006).

\subsubsection{A Framework for $\mathrm{C} 2 \mathrm{C}$ Tourism Collaboration}

Based on the existing literature, in this study, the city-city collaboration utilises the following components:

a. Enabling governance: $\mathrm{C} 2 \mathrm{C}$ has a strong enabling leadership support that ensures decision making. Planning and implementations would be favourable and lessen unnecessary regulations.

b. Shared goals and implementation: Sharing similar goals, followed by ease of implementations at all levels of tourism providers will accelerate tourism.

c. Complimentary and reciprocity: Both regions complement each other in terms of products and services.

d. Participating Community: Community of both regions participates in the collaboration as a tourist, users and tourism business providers.

e. Homogeneity of emerging consumer: The region contributes to the emerging consumer and users in tourism.

f. Geographical location and accessibility: These factors make both regions viable to collaborate and visits. 


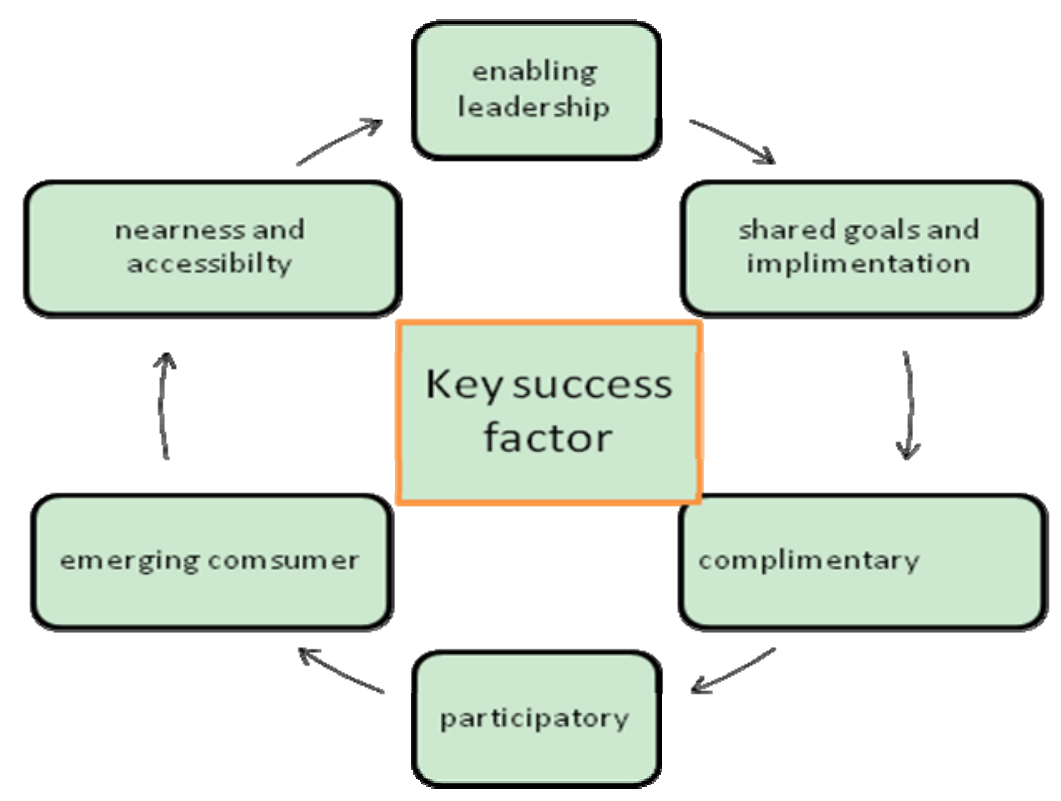

Figure 1. Framework of the study

\subsection{The Study Area}

This study area comprised the Straits of Malacca development region; of which Malacca and Riau Provincials are representing Malaysia and Indonesia respectively. Malacca has a long history of civilization and colonialism (Ho, 2009; Nordin, 2008; Gerke \& Evers, 2011). Being one of the earliest centres of trade and commercialization, tourism, nevertheless, is part of the state's pride. Malacca has been awarded as the World Heritage Sites in 2009, together with Penang.

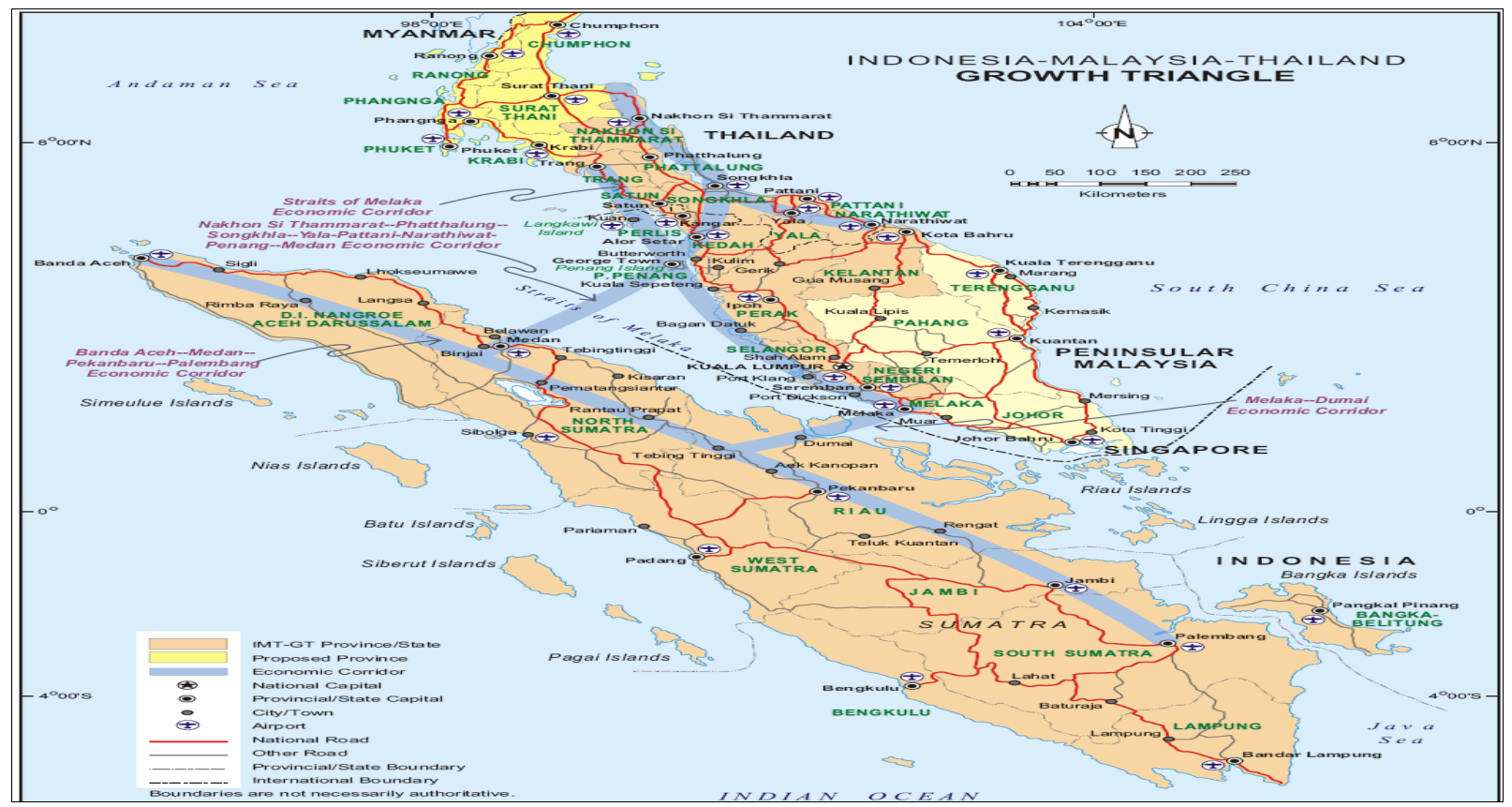

Figure 2. Study area

Source: IMT-GT_Implementation_Blueprint_2012-2016.pdf 
In 2010, Malacca was declared as the developed state, using the criteria set by UNDPs. Tourism is one of the key drivers of growth, and tourism trends show that the historical sites have been able to attract more than the state targeted figure. In 2010, the state has attracted more than 8.2 millions of tourists and 11 million of tourist arrivals for the 2011. The state will not achieve to the existing standard without a proper planning and development. It has identified 12 major products and these include heritage, recreation and thematic events.

The Riau Provincials, on the other hand, is one of the major cross border neighbours in the Straits of Malacca. The development is governed by the Riau Vision 2020, whereby the Riau Province acts as a centre of economic and Malay culture within a religious society, prosperous physically and spiritually in Southeast Asia by 2020 . Riau Provincial comprises nine districts and two cities: Kuantan Singingi, Indragriri Hulu, Indragiri Hilir, Pelalawan, Siak, Kampar, Rokan Hulu and Hilir, Bengkalis, Dumai City and Pekan Baru City. It has a population of almost 770,000, a big number of markets for various consumer goods and services, including tourism. The Riau provincial has vast and diverse tourism attractions, ranging from heritage, culture and the nature of religious, shopping and man-made attractions.

Both Malacca and Sumatera share the Straits of Malacca waterway, an ancient trading route (Rusli, 2012; Nordin, 2008; Gerke \& Evers, 2011; Evers \& Gerke, 2006). From the waterways that ferried traditional commodities like spices, camphor and nutmegs in its bygone eras to modern shipments of crude oil, petroleum products, electronic goods and motor vehicles, the Straits of Malacca has its reputation as one of the most crucial shipping lanes and the longest straits used for international navigation (Nordin, 2008; Rusli, 2012; Ho, 2009). The Straits of Malacca contributes to the diversification of an economic sector not only in the fishing industry, but its richness in biodiversity; historical and cultural values strengthen the tourism sector. Designations of Tanjung Piai as a Ransar site and Pulau Langkawi as the UNESCO's World Geopark can provide the impetus for further collaboration initiatives in the Straits of Malacca development region (Rosli, 2012).

\subsection{Data Collection and Analysis}

This study took place in Malacca and Riau Provincials, with special attempts to Banda Hilir and Dumai, Pekan Baru and Bengkalis of which representing the study areas respectively. The primary and secondary data were utilized to elicit the collaborative initiatives and measures, from both perspectives the supply and demand side. All field data collection was done in May to July, 2010, while the additional data collected through the website was done in 2010 and 2011. Looking into how the data collection was organized in Malacca, several field visits to the stakeholders' agencies were initiated. For tourism providers' perspectives, face-to-face and the self-administrative survey were conducted on the purposive samples of tourism businesses in Banda Hilir. From the Riau Provincial side, field visit, however, undertook a focus group discussion to collect both primary and secondary. These two field visits have made us possible in collecting the collaborative measures among the tourism providers as well as the government agencies. This included questions pertaining to the categorization of goods and services, reasons for collaboration, prospects and challenges. From the demand side, this study used results partially derived from the tourist survey conducted in both study areas. The tourists' survey conducted in Dumai, Pekan Baru and Bengkalis have given due to consideration on the tourists' demand and visitation pattern during their stay in Malacca. Meanwhile, the tourist survey at Malacca provided a profiling of the Indonesian tourists' experience of the heritage site of Banda Hilir. The qualitative data collected was analyzed descriptively, and the survey data were analyzed with the SPSS version 16 especially in deriving the tourists' site preferences.

\section{Results and Discussion}

\subsection{Enabling Leadership}

As the literature reveals that the understandings and commitments from both stakeholders determine the extent of the overall $\mathrm{C} 2 \mathrm{C}$ collaboration, this study exhibits recent leadership-led initiatives to tourism collaboration. Added to the enabling leadership factor, the historical legacy of two stakeholders at the state or local levels of both Malacca and Riau play significant roles in realizing city-city tourism. Bilateral meetings, delegates and working visits from both government agencies organized in both Malacca and Pekan Baru or Dumai are shown in Table 1. 
Table 1. An enabling leadership of Malacca-Riau

\begin{tabular}{|c|c|c|c|c|}
\hline \multicolumn{5}{|c|}{ Visit Form Malacca delegates to Provincial Riau } \\
\hline $\begin{array}{l}\text { Stakeholders and } \\
\text { sector }\end{array}$ & $\begin{array}{l}\text { Level of } \\
\text { governance }\end{array}$ & Agenda & Year & Sector \\
\hline $\begin{array}{l}\text { Chief Minister with } \\
\text { Entrepreneurs }\end{array}$ & State level & $\begin{array}{l}\text { Visit Rupat and Dumai for } \\
\text { collaboration prospects in new } \\
\text { growth centres. }\end{array}$ & 2003 & $\begin{array}{l}\text { Regional and spatial } \\
\text { consideration }\end{array}$ \\
\hline $\begin{array}{l}\text { Managing Director } \\
\text { of Melaka } \\
\text { International Trade } \\
\text { Centre meeting with } \\
\text { Riau Governor }\end{array}$ & $\begin{array}{l}\text { State government } \\
\text { and trade sector }\end{array}$ & $\begin{array}{l}\text { Delegates' visits to the Riau } \\
\text { Governor, attending } \\
\text { Convention of Malay } \\
\text { Islamic World (DMDI) }\end{array}$ & 2004 & $\begin{array}{l}\text { Business } \\
\text { opportunities }\end{array}$ \\
\hline $\begin{array}{ll}\text { Chairman } & \text { of } \\
\text { Tourism Melaka } & \end{array}$ & $\begin{array}{l}\text { Governance and } \\
\text { Tourism sector }\end{array}$ & $\begin{array}{l}\text { Visit to the ancient governance of } \\
\text { Kampar; meeting for Footprints of } \\
\text { Melaka governance project. }\end{array}$ & 2007 & $\begin{array}{l}\text { Governance } \\
\text { tourism }\end{array}$ \\
\hline Chief Minister Visit & $\begin{array}{l}\text { State government } \\
\text { and tourism }\end{array}$ & $\begin{array}{l}\text { Officiating DMDI gallery at } \\
\text { Museum of Sang Nila Utama, } \\
\text { Pekan Baru }\end{array}$ & 2009 & $\begin{array}{l}\text { Specialized tourism } \\
\text { - Museum. }\end{array}$ \\
\hline $\begin{array}{l}\text { Delegates of State } \\
\text { Officials }\end{array}$ & $\begin{array}{l}\text { State Government } \\
\text { and Transportation } \\
\text { Sector }\end{array}$ & $\begin{array}{l}\text { Discussion on Operation of Roll on } \\
\text { Roll Off (RO-RO), sea } \\
\text { transportation between } \\
\text { Dumai-Malacca and the State } \\
\text { Government of Malacca and } \\
\text { BAPPEDA (Badan Perencanaan } \\
\text { Pembangunan Daerah) Riau. }\end{array}$ & 2009 & $\begin{array}{l}\text { Infrastructural } \\
\text { development } \\
\text { accessibility } \\
\text { consideration }\end{array}$ \\
\hline Chief Minister & $\begin{array}{l}\text { State Government } \\
\text { and Tourism }\end{array}$ & Malacca Travel Mart in Riau & 2004 & Travel and tourism \\
\hline \multicolumn{5}{|c|}{ Visit from Riau delegates to Malacca } \\
\hline $\begin{array}{l}\text { Visit from Riau } \\
\text { Gabenor to Malacca } \\
\text { for } \\
\text { meeting }\end{array}$ & $\begin{array}{l}\text { State government } \\
\text { and communication } \\
\text { sector }\end{array}$ & $\begin{array}{l}\text { Discussion on ferry services or } \\
\text { Ro-Ro facilities for transportation } \\
\text { efficiency between the two ports. }\end{array}$ & 2009 & $\begin{array}{l}\text { Infrastructural } \\
\text { development } \\
\text { tourism }\end{array}$ \\
\hline $\begin{array}{l}\text { Riau Governor and } \\
\text { delegates }\end{array}$ & $\begin{array}{l}\text { Provincial officials } \\
\text { and DMDI officials }\end{array}$ & $\begin{array}{l}\text { Convention of Malay World, } \\
\text { Islamic World held on } 22-24 \\
\text { December } 2008 \text { in Melaka. }\end{array}$ & 2008 & Convention tourism \\
\hline Riau Governor & Provincial officials & $\begin{array}{l}\text { Social and political visit during } \\
\text { Official state award, Melaka }\end{array}$ & 2010 & Social and political \\
\hline $\begin{array}{l}\text { Riau Governor and } \\
\text { delegates }\end{array}$ & $\begin{array}{l}\text { Provincial officials, } \\
\text { tourism officials }\end{array}$ & DMDI Convention in Melaka & 2011 & $\begin{array}{l}\text { Business among the } \\
\text { Malays }\end{array}$ \\
\hline $\begin{array}{l}\text { Riau Governor and } \\
\text { delegates }\end{array}$ & $\begin{array}{l}\text { Provincial officials, } \\
\text { tourism officials }\end{array}$ & $\begin{array}{l}\text { The 10th Convention of DMDI in } \\
\text { Melaka }\end{array}$ & 2010 & $\begin{array}{l}\text { Business among the } \\
\text { Malays }\end{array}$ \\
\hline $\begin{array}{l}\text { Riau Governor and } \\
12 \text { heads of } \\
\text { ministerial in Riau } \\
\text { Province. Delegates }\end{array}$ & $\begin{array}{l}\text { Provincial officials, } \\
\text { tourism officials }\end{array}$ & $\begin{array}{l}\text { Meeting between the state } \\
\text { government of Malacca and Riau } \\
\text { Province, discussing on the } \\
\text { strategies of private involvement in } \\
\text { economic sector. }\end{array}$ & 2011 & $\begin{array}{l}\text { Private-led } \\
\text { collaboration }\end{array}$ \\
\hline
\end{tabular}

Source: Authors' analysis on official websites of both study areas in 2010 and 2011.

From Table 1, results shown that the meetings, official and social visits were within the basis of cooperation and reciprocity in the tourism-related business, promotion and marketing. In fact, with the enabling approach for the product development assistance, not only the Pekan Baru tourism providers have benefited from these opportunities, other small countries including Sawah-lunto had benefited from such collaboration, particularly in enhancement of historical tourism, museum and cultural tours. The study shows that despite having different stages of tourism development, win-win collaboration can still be practiced between the Malacca and the Riau province collaboration actors. 
The data also indicate that the business communities of the two cities are proactive, taking the advantages of the macro environment, including the ASEAN Economic Community 2015 and inter regional cooperation. The ASEAN collaboration involved a large number of local political actors ranging from the City Council until the tourism providers themselves. In fact, the changing policy of centralization to decentralization policy in development has helped the Riau government to seek opportunities with the neighbouring state, especially Malacca (Furqan \& Som, 2010; Efendi, 1999).

\subsection{Engaging in Shared Goals and Practices}

The collaboration success will depend, to some extent, on the clarity and the reciprocity of the goals and vision, followed by the realization of implementations. Being members of ASEAN and regional cooperation of IMT-GT, both Melaka and Riau seem to work closely in achieving a shared vision and goals (Ford \& Lyons, 2006). In fact, a shared vision and goals to achieve high growth is not a new agenda for the last three decades. This can be traced at various levels, be it of regional or local levels. At the ASEAN level, all members have agreed on the sustainable tourism as cited below:

By 2015, ASEAN will provide an increasing number of visitors to the region with authentic and diverse products, enhanced connectivity, a safe and secure environment, increased quality of services, while at the same time ensuring an increased quality of life and opportunities for residents through responsible and sustainable tourism development by working effectively with a wide range of stakeholders.

(ASEAN, 2011)

Whilst at the regional tourism, collaboration was assisted with joint promotion, trade policy and incentives, the findings showed, at the local level of Malacca-Riau collaboration, diverse range of business ventures is now an emerging phenomenon. The tourism providers either collaborate in the business venture in Malacca or acting as the providers of stocks and goods to their business counterparts and suppliers of the human capital or talent workers in tourism services. Table 2 shows the emerging diversity of tourism services derived from partnerships in promotion, marketing, events hosting and performing arts.

Table 2. Tourism networking in selected sectors

\begin{tabular}{|c|c|c|}
\hline $\begin{array}{l}\text { Subsector of } \\
\text { Tourism Providers }\end{array}$ & Premises & Partnership \\
\hline Food gastronomy & $\begin{array}{l}\text { Restaurants and food outlets } \\
\text { in selected areas. }\end{array}$ & $\begin{array}{l}\text { The businesses were operated in the form of local } \\
\text { ownership who have traits of social contacts and } \\
\text { marriage, the offering of Indonesian food is considered } \\
\text { an opportunity of social cultural similarity }\end{array}$ \\
\hline Fashions & Boutique and shop & $\begin{array}{l}\text { Provides stock and supply of update Muslim fashions } \\
\text { and embroideries from Bukit Tinggi }\end{array}$ \\
\hline Hotels & $\begin{array}{l}\text { Training, chef, management } \\
\text { professionals and internships }\end{array}$ & $\begin{array}{l}\text { Several hotels receive students' internship from the } \\
\text { Sumatera universities }\end{array}$ \\
\hline $\begin{array}{l}\text { Souvenirs and } \\
\text { Craft, Furniture }\end{array}$ & Souvenirs, furniture shops & $\begin{array}{l}\text { Business operation - goods and ready-made products, } \\
\text { suppliers from counterparts including Bukit Tinggi and } \\
\text { Bandung. Specialized home furniture and furnishings } \\
\text { human capitals were imported from Sumatera. } \mathrm{Dr} \text { Kayu, } \\
\text { a popular nickname for carpentry indicates the existence } \\
\text { of close collaboration between operators and showroom } \\
\text { managers. }\end{array}$ \\
\hline Medical Tourism & $\begin{array}{l}\text { Both regions benefited from } \\
\text { the medical tourism, }\end{array}$ & $\begin{array}{l}\text { As niche tourism, availability of Medical clinics and } \\
\text { extension services in Pekan Baru and Dumai showed a } \\
\text { close link of guaranteed customers-specialists. }\end{array}$ \\
\hline Cultural attraction & $\begin{array}{l}\text { Dance and cultural shows - } \\
\text { staged. }\end{array}$ & Cultural shows are promoted. \\
\hline
\end{tabular}

\subsection{Tourists' Preferences Reciprocity}

Being a tourism destination, both Malacca and Riau Province have to bear with the competing offering and demand of the existing and future tourist market of this region. Taking into account the destination is defined as 'amalgam of individual products and experience opportunities that combine to form a total experience of the area visited" (Murphy et al., 2000, p. 44), the products of Strait of Malacca Development region, therefore, can be 
envisaged at a wider product offering, beyond the geographical areas. In this respect, Malacca being one of the World Heritage Sites has much advantage over the Riau Province tourism sites.

The survey results, however, have shown that Malacca has attracted more Riau tourists instead of vice versa. When visiting Malacca, the Riau tourists were found to favor attractions and services not available to their counterparts or locality. More apparent, their choice of attractions was made during the pre-visit or before departure to holidaying. Historical, medical, cultural and shopping was their major activities consumed during their stay in Malacca. Agro-based attractions, nevertheless, were less attractive as they could experience similar sites at their origin. Youth tourism was not really clear among the product labelling. In this regard, travels to Malacca were experienced or consumed in a complementary perspective among the Riau tourists.

\subsection{The Melayuness Factor}

As most of the tourism collaboration and city-city collaboration generally lacks of participating communities, social-cultural ties and inclusiveness, this study instead, has significantly shown the strength of both factors. Several authors regard the Melayuness factor (Azhar, n. d.) or 'We are playing relatives' (Tjandradewi et al., 2006) as crucial factors in determining strong city-city tourism. As Riau is regarded as the Malay land of the Indonesian Archipelago, many of the key respondents agreed that this factor played important roles since the existence of Malacca history hundreds years ago until today. The strong Malay factor had been the key influential for operating services in gastronomy, furniture and decorative arts, fashions as well as staged performing arts.

From the data gathered for food and culinary services in Banda Hilir, the study found that many Malacca dishes were similar to the Malay-Riau dishes. Among the tourists' responses, substantial operations of Minang's food and Indonesian gastronomy restaurants were well accepted as part of the Malacca's historical link to its neighbouring states many decades ago. The popular food easily found and served in Malacca were the Nasi Padang, dendeng, bakso and Asam Pedas. The existence of the closer ties in the food and gastronomy is linked to the restaurant owners' initiatives to import professional chefs, manpower, recipes and raw ingredients from Riau and Sumatera archipelago. Another factor that expedites collaboration in gastronomy services is the homogeneity of Bahasa Melayu or Malay language as the lingua Franca of both regions. It is found that homogeneity of culture not only exhibits in the cultural performances, but it had a strong bearing in determining the regional consumers' taste (Hamzah et al., 2011).

\subsection{Emerging Consumers of the Malacca Straits Development Region}

As many scholars have agreed upon the fact that a guarantee of growing markets in the collaborative region helps to strengthen business opportunities (Hampton, 2006; Hamzah et al., 2011), opinions from our key respondents during the focus group discussion in Dumai and Pekan Baru seemed to verify the existence of this phenomena. Simply, consumers of this region play significant roles not only in tourism, but also in education, consumerism and lifestyle.

In fact, a growing demand of two collaborative regions is not a new agenda for the Straits of the Malacca development region. Besides ASEAN has similarities in the tourists' origin among its members, the influx of intra-region tourists in this region is also overwhelming. The tourist arrival statistics from Malacca to Riau or vice versa provide empirical evidence that both areas act as the provider and the recipient between these two connecting regions. Those travelling from Riau to Malacca were involved in the medical tourism, shopping, leisure and Visit Friends and Relatives. While the Malaysian or the Malacca citizenry who travelled to Dumai or Pekan Baru, have also extended their stay to Bukit Tinggi, making the Riau Province a favorable shopping and highland destination. This trend provides a continuous demand, and a large pool of 700,000 populations of the Riau Provincial will mean a strong basis of regional market in the near future.

As the collaboration is centred to tourism, it is therefore, vital for the tourism product mix of this region to achieve quality services' compliance to both market needs. To date, Malacca showcased 12 major tourism products, and Riau provides varieties of tourism products. From the tourists' survey undertaken during the study, we found significance of the preferences among the Sumatran tourists vacationing in Malacca. The study indicates that both Malacca and Riau Provincials have much to offer to the consumers within the region. From the tourist's perspective, Malacca has a wide range of attractions, from low to high cultural attraction; and leisure, history, shopping and medical tourism were among the fourth popular choices (Table 3). The Riau Provincials, on the other hand, provide unique sites of culture and heritage, including the highland attraction of Bukit Tinggi, which became one of the preferences of the Malaysian tourists. 
Table 3. Rank sector of preferences before tour and at the destination

\begin{tabular}{lcc}
\hline Tourism sub-sector & Rank of choice before tour/visit & Rank of actual tour/visit \\
\hline Historical & 1 & 1 \\
Culture & 4 & 3 \\
Recreation and leisure & 3 & 4 \\
Sport & 11 & 11 \\
Shopping & 5 & 5 \\
Convention & 12 & 9 \\
Medical & 2 & 2 \\
Education tourism & 6 & 6 \\
Agro tourism & 8 & 12 \\
Gastronomy/Culinary & 7 & 7 \\
Second home & 9 & 8 \\
Youth tourism & 10 & 10 \\
\hline
\end{tabular}

Added to the existing demand are the emerging new regional and international consumers. At the international scenario, Malacca, declared as a developed state and a World Heritage Site will become the universal advantage of niche tourism to be shared with the Riau's counterpart. Furthermore, at the ASEAN level, the implementation of an economic zone in 2015 will provide more impetuses to strike for development that can be mutually shared among members.

\subsection{Geographical Location and Accessibility}

As asserted in the literature of cross border tourism and city to city tourism, closeness and accessibility also determine the extensiveness of the city to city tourism between Malacca and Riau-Pekan Baru. In terms of accessibility, the intercity to city and state - provincial are the major concerns of both stakeholders. Furthermore, from our fieldwork, efficient ferry services expedite the cross-border travel from the entry-exit points of the Provincials: Rupat, Pekan Baru and Dumai. Our key respondents' stress on the close proximity to Malacca was not only based on the recent development, but it has long established, ever since the existence of power relation, trade and social visits between two communities staying in both areas. They considered that travelling to these two regions as an intra-travel instead of inter-travel practices.

\section{Conclusion}

Although business ventures have a long standing history in Asian countries, this study affirms an emerging of tourism collaboration in the Straits of Malacca Development Region. The rising collaboration in the city to city tourism is closely linked to the critical success factors that both actors have to bear and take advantage. Based on the analysis undertaken during the study, key success factors are significantly evident to the macro and at the micro level of the individuals, community and the businesses. First, at the governance level, leadership commitment and managerial talents are central to support these initiatives. Unlike most examples in the existing literature that stress upon the unbalance benefits between collaborators, the results reveal a vice versa in the case throughout the Malacca Strait development region. The relevant government stakeholders have had mutual benefits in these undertakings. Second, within the business entities, sharing of the possibilities in creating tourism businesses serve a strong support for both areas, especially in exploring the Malayness or Melayuness as a taste maker. Third, within the context of community's regional entity, the inclusiveness of the Malay community acts as a strong pillar for travelling in both regions. Fourth, within the spatial developmental areas, optimising the consumers, resources and physical proximity have provided prospects to encounter with the pressing globalising business challenges and tourist changing scenario.

From this study, even though there is a great challenge in searching the best collaborative partnership, recreating on the potentials of the legacy of the Straits is worth exploring. As this study concentrates on Malacca and Riau Provincials, it is suggested that further study of collaboration to be explore in the secondary or smaller exit-entry point between both beneficiaries. Among the potential, exit points include the Kukup-Belawan and Stulang Laut-Bintan and Rupat-Kuala Linggi. This future study can weigh the aggregate of the actual beneficiaries in the 
contexts of historical traits as well as potential markets of city-city tourism. Furthermore, as tourism networks are diverse and unique within these regions, this finding still has the limitation in generating comprehensive lessons and insights for tourism businesses. For that reason, the authors propose the future study which allows partners to explore a wider scope of tourism activities to increase inter-organizational relationships in both collaborative regions of the Malacca Straits, especially in connecting its hinterlands.

\section{Acknowledgement}

The authors wish to express their appreciations to the Riau and Malacca stakeholders during the focus group discussion and field survey. The research was fully supported from the UKM grant and partially a recent grant Dana Pembangunan Penyelidikan PTJ DPP-2013-169, entitled Tourism product development in Malaysia and Fundamental Research Grant (FRGS/1/2013/SS08/UKM/02/1) awarded by the Ministry of Education, Malaysia.

\section{References}

Aas, C., Ladkin, A., \& Fletcher, J. (2005). Stakeholder collaboration and heritage management. Annals of Tourism Research, 32(1), 28-48. http://dx.doi.org/10.1016/j.annals.2004.04.005

Arnaboldi, M., \& Spiller, N. (2011). Actor-network theory and stakeholder collaboration: The case of cultural districts. Tourism Management, 32, 641-654. http://dx.doi.org/10.1016/j.tourman.2010.05.016

ASEAN. (2011). Asean tourism strategic plan. Retrieved March 28, 2012, from http://www.aseansec.org/ documents/ATSP 25202011-2015.pdf+asean +tourism+2015

Asian Development Bank. (2012). Asian expanding horizons: A study on the development of the Indonesia, Malaysia, Thailand Growth-Triangle Economic Connectivity Corridors. Retrieved January 5, 2012, from http://www.imtgt.org/Documents/Studies/expanding-horizons-study.PDF

Azhar, A. (n. d.). Malayness in Riau: The study and revitalization of identity. Retrieved January 5, 2012, from http://www.sabrizain.org/malaya/library/riaumalayness.pdf

Beritelli, P. (2011). Cooperation among prominent actors in a tourist destination. Annals of Tourism Research, 38(2), 607-629. http://dx.doi.org/10.1016/j.annals.2010.11.015

Bramwell, B., \& Sharman, A. (1999). Collaboration in local tourism policymaking. Annals of Tourism Research, 26(2), 392-415. http://dx.doi.org/10.1016/S0160-7383(98)00105-4

Brune, F. E. (2006). Cross-Border City Cooperation in the Baltic Sea. Master Thesis. WWU Münster Universiteit Twente. Institut für Politikwissenschaft - Faculteit Bestuurskunde. Retrieved February 6, 2012, from http://www.essay.utwente.nl/57698/1/scriptie_Brune.pdf

Buis, H. (2009). The role of local government associations in increasing the effectiveness of city-to-city cooperation. Habitat International, 33, 190-194. http://dx.doi.org/10.1016/j.habitatint.2008.10.017

Bunnell, T., Muzaini, H., \& Sidaway, J. (2006). Global city frontiers: Singapore's hinterland and the contested socio-political geographies of Bintan, Indonesia. International Journal of Urban and Regional Research, 30(1), 3-22. http://dx.doi.org/10.1111/j.1468-2427.2006.00647.x

D'Angella, F., \& Go, F. M. (2009). Tale of two cities' collaborative tourism marketing: Towards a theory of destination stakeholder assessment. Tourism Management, 30, 429-440. http://dx.doi.org/10.1016/j.tourman.2008.07.012

Villiers, J. C. D. (2009). Success factors and the city-to-city partnership management process - from strategy to alliance capability. Habitat International, 33(2), 149-156. http://dx.doi.org/10.1016/j.habitatint.2008.10.018

Dredge, D. (2006). Policy networks and the local organisation of tourism. Tourism Management, 27, 269-280. http://dx.doi.org/10.1016/j.tourman.2004.10.003

Effendi, E. S. (2009). The impact of region competitiveness on industry's performance: A study in tourism industry in Batam and Bintan. Riau Islands, Indonesia. Retrieved August 26, 2011, from http://www.spp.nus.edu.sg/.../A_Study_In_Tourism_Industry_In_Batam_and_Bintan

Evers, H. D., \& Gerke, S. (2006). The strategic importance of the Straits of Malacca for world trade and regional development. Working paper series, Department of Political and Cultural Change. Bonn. Retrieved April 6, 2012, from http://papers.ssrn.com/sol3/papers.cfm?abstract_id= 1020877

Ford, M. T., \& Lyons, L. T. (2006). The borders within: mobility and enclosure in the Riau Islands. Asia Pacific Viewpoint, 47(2), 257-271. http://dx.doi.org/10.1111/j.1467-8373.2006.00312.x 
Furqan, A., \& Som, A. P. M. (2010). Effects of decentralization policy on island destination in Indonesia. World Applied Sciences Journal (Special Issue of Tourism \& Hospitality), 10, 63-70.

Gelbman, A., \& Timothy, D. J. (2011). Border complexity, tourism and international exclaves a case study. Annals of Tourism Research, 38(1), 110-131. http://dx.doi.org/10.1016/j.annals.2010.06.002

Gerke, S., \& Evers, H. D. (2011). Melaka Straits. A Narrow band for world trade. Akademika, 81(1), 5-14.

Go, F. M., \& Williams, P. A. (1993). Competing and cooperating in the changing tourism channel system. Communication and channel systems in tourism marketing. Journal of Travel \& Tourism Marketing, 2(2/3), 229-248.

Go, F., \& Fenema, P. C. V. (2006). Moving bodies and connecting minds in space: a matter of mind over matter. In S. Clegg, \& M. Kornberger (Eds.), Space, organizations and management theory. Malmo: Liber \& Copenhagen Business School Press.

Habibah, A. (1994). Tourism industry in ASEAN: a challenge (Industri pelancongan di ASEAN: satu cabaran). Akademika, 44, 15-44.

Habibah, A., Hamzah, J., \& Kurnia, A. (2009). Jaringan strategik negeri provinsi sebagai alternatif untuk memperkasakan jaringan ekonomi wilayah Malaysia-Indonesia, Proceeding Seminar Kebangsaan Ekonomi Malaysia ke-IV, Fakulti Ekonomi dan Perniagaan, Universiti Kebangsaan Malaysia.

Habitat. (2001). City-to-City Cooperation: issues arising from experience. United Nations Centre for Human Settlements. Retrieved March 2, 2012, from http://www.un.org/ga/Istanbul+5/city-to-city.pdf

Hall, C. M. (1999). Rethinking collaboration and partnership: a public policy perspective. Journal of Sustainable Tourism, 7(3/4), 275-289.

Hampton, M. (2006). The socio-economic impacts of Singaporean cross-border tourism in Malaysia and Indonesia. Working Paper Series. University of Kent. Retrieved April 8, 2012, from http://kar.kent.ac.uk/23112/1/Hampton_WP184_Cross_border_tourism.pdf

Hamzah, J., Habibah, A., Buang, A., \& Kurnia, A. (2011). Melaka as Indonesian tourist gateway: Responding to global challenges. GEOGRAFIA Online. Malaysian Journal of Society and Space, 7 Special Issue: Social and Spatial Challenges of Malaysian Development, 2-13.

Ho, J. H. (2009). Enhancing safety, security and environmental protection of the Straits of Malacca and Singapore: the co-operative mechanism. Ocean Development and International Law, 40(2). http://dx.doi.org/10.1080/00908320902864854

Ho, K. C. (1997). Semi periphery and borderland integration: Singapore and Hong Kong experience. Political Geography, 16(3), 241-259. http://dx.doi.org/10.1016/0962-6298(95)00136-0

Hsu, C., \& Zu, Z. (2009). Regional tourism collaboration in the Pearl River Delta. China. Retrieved August 14, 2011, from http://www.scholarworks.umass.edu/cgi/viewcontent.cgi?article=1006\&context

Hunaidi. (2005). Menuju model pengembangan kawasan perbatasan daratan antar negara (Studi Kasus: Kecamatan Paloh dan Sajingan Besar, Kabupaten Sambas, Kalimantan Barat). Universitas Diponegoro Semarang. Retrieved April 14, 2012, from http://www.eprints.undip.ac.id/17459/1/H_U_S_N_A_D_I.pdf

IMT-GT organization. (n. d.). IMT-GT Implementation Blue Print 2012-2016. Retrieved from http://imtgt.org/Documents/IMT-GT_Implementation_Blueprint_2012-2016.pdf

Jamal, T. B., \& Getz, D. (1995). Collaboration theory and community tourism planning. Annal of Tourism Research, 22(1), 186-204.

Kim, T. Y. (2010). Establishment of a tourism network in the Korea-Japan Strait. Retrieved August 21, 2011, from http://www.region.go.kr/jeju_conference/SESSION5_4.pdf

Lemmetyinen, A., \& Go, F. M. (2008). The key capabilities required for managing tourism business networks. Tourism Management, 30, 31-40. http://dx.doi.org/10.1016/j.tourman.2008.04.005

Litvin, S. W., \& Ling, S. N. S. (2001). The destination attribute management model: an empirical application to Bintan, Indonesia. Tourism Management, 22, 481-492. http://dx.doi.org/10.1016/S0261-5177(01)00003-6

Luo, X., \& Shen, J. (2009). A study on inter-city cooperation in the Yangtze River Delta region, China. Habitat International, 33(1), 52-62. http://dx.doi.org/10.1016/j.habitatint.2008.04.002 
Mandják, T., Simon, J. J., \& Szalka, Z. (2011, July 30). A framework for the analysis of global, regional and local business networks. Industrial Marketing Management, In Press, Corrected Proof. http://dx.doi.org/10.1016/j.indmarman.2011.07.003

March, R., \& Wilkinson, I. (2009). Conceptual tools for evaluating tourism partnerships. Tourism Management 30, 455-462. http://dx.doi.org/10.1016/j.tourman.2008.09.001

Masakatsu, O. (2004). The issues of inter-city networking-for tourism development in The Asia Pacific. Ritsumeikan International Affairs, 2, 195-203.

Mistilis, N., \& Daniele, R. (2004). Challenges for competitive strategy in public and private sector partnerships in electronic national tourist destination marketing systems. Journal of Travel and Tourism Marketing, 17(4), 63-73. http://dx.doi.org/10.1300/J073v17n04_06

Mostert, E., Pahl-Wostl, C., Rees, Y., Searle, B., Tàbara, D., \& Tippett, J. (2007). Social learning in European river-basin management: barriers and fostering mechanisms from 10 river basins. Ecology and Society, 12(1), 19. Retrieved from http://www.ecologyandsociety.org/vol12/iss1/art19/

Muñoz-Erickson, T. A., Cutts, B. B., Larson, E. K., Darby, K. J., Neff, M., Wutich, A., \& Bolin, B. (2010). Spanning boundaries in an Arizona watershed partnership: information networks as tools for entrenchment or ties for collaboration? Ecology and Society, 15(3), 22. Retrieved from http://www.ecologyandsociety.org/vol15/iss3/art22/

Murphy, P., Pritchard, M. P., \& Smith, B. (2000). The destination product and its impact on traveller perceptions. Tourism Management, 21, 43-52. http://dx.doi.org/10.1016/S0261-5177(99)00080-1

Nordin, H. (2008, May). Geography and trade: importance of the Straits of Malacca to World Trade, Asia and Malays World 1700-1800. Akademika, 73, 3-26.

Reid, L. J., Smith, S. L. J., \& McCloskey, R. (2009). The effectiveness of regional marketing alliances: a case study of the Atlantic Canada Tourism Partnership 2000-2006. Tourism Management, 29, 581-593. http://dx.doi.org/10.1016/j.tourman.2007.05.005

Roper, S. (2007). Cross-border and local co-operation on the island of Ireland: An economic perspective. Political Geography, 26, 554-574. http://dx.doi.org/10.1016/j.polgeo.2007.04.002

RSIS. (2007). Riau Roundtable 2007. Opportunities and challenges in the Riau Archipelago and Riau Province report on a conference organized by The Indonesia Programme of the S. Rajaratnam School of International Studies. Retrieved December 23, 2012, from http:www.rsis.edu.sg/publications/conference_reports/Riau_report.pdf

Rusli, M. H. B. M. (2012). Protecting vital sea lines of communication: a study of the proposed designation of the Straits of Malacca and Singapore as a particularly sensitive sea area. Ocean \& Coastal Management, 57, 79-94. http://dx.doi.org/10.1016/j.ocecoaman.2011.12.003

Selin, S., \& Chavez, D. (1995). Developing an evolutionary tourism partnership model. Annals of Tourism Research, 22, 844-856. http://dx.doi.org/10.1016/0160-7383(95)00017-X

Shen, C. H., \& Lin, M. R. (2011). The determinants of cross-border consolidation in eight Asian countries: Before and after the Asian financial crisis. J. of Multi. Fin. Manag. 21, 89-105. http://dx.doi.org/10.1016/j.mulfin.2010.12.001

Shih, H. Y. (2006). Network characteristics of drive tourism destinations: an application of network analysis in tourism. Tourism Management, 27, 1029-1039. http://dx.doi.org/10.1016/j.tourman.2005.08.002

Slinger, J. H., Hilders, M., \& Juizo, D. (2010). The practice of transboundary decision-making on the Incomati River: elucidating underlying factors and their implications for institutional design. Ecology and Society, 15(1), 1. Retrieved from http://www.ecologyandsociety.org/vol15/iss 1/art1/

Sofield, T. H. B. (2006). Border tourism and border communities: An overview. Tourism Geographies, 8(2), 102-121. http://dx.doi.org/10.1080/14616680600585489

Tjandradewi, B. I., \& Marcotullio, P. J. (2009). City-to-city networks: Asian perspectives on key elements and areas for success. Habitat International, 33(2), 165-172. http://dx.doi.org/10.1016/j.habitatint.2008.10.021

Tjandradewi, B. I., Marcotullio, P. J., \& Kidokoro, T. (2006). Evaluating city-to-city cooperation: a case study of the Penang and Yokohama experience. Habitat International, 30(3), 357-376. http://dx.doi.org/10.1016/j.habitatint.2004.10.001 
United Nations Centre for Human Settlements. (2001). City-to-City cooperation: issues arising from experience. An interim report. IULA/UTO Unity Congress, Rio de Janeiro, 3-6 May 2001 and on city-to-city cooperation at the 25th United Nations General Assembly Special Session (Istanbul+5) New York, 6-8 June 2001.

Wiemer, C. (2009). Three cases of cross-border economic corridor development with lessons for the Greater Mekong Sub-Region. Retrieved April 11, 2012, from http://callawiemer.com/Documents/Wiemer\% 20Corridor\%20Study. pdf

Wollenberg, E., Iwan, R., Limberg, G., Moeliono, M., Rhee, S., \& Sudana, M. (2007). Facilitating cooperation during times of chaos: spontaneous orders and muddling through in Malinau District, Indonesia. Ecology and Society, 12(1), 3. Retrieved from http://www.ecologyandsociety.org/vol12/iss1/art3/

Wong, E. P. Y., Mistilis, N., \& Dwyer, L. (2010). Understanding ASEAN tourism collaboration-Preconditions and policy framework formulation. International Journal of Tourism Research, 12(3), 291-302. http://dx.doi.org/10.1002/jtr.757

Wong, E. P. Y., Mistilis, N., \& Dwyer, L. (2011). A framework for analyzing intergovernmental collaboration. The case of ASEAN tourism. Tourism Management, 32, 367-376. http://dx.doi.org/10.1016/j.tourman.2010.03.006

\section{Copyrights}

Copyright for this article is retained by the author(s), with first publication rights granted to the journal.

This is an open-access article distributed under the terms and conditions of the Creative Commons Attribution license (http://creativecommons.org/licenses/by/3.0/). 